\title{
IMPROVEMENT OF EGYPTIAN TALC QUALITY FOR INDUSTRIAL USES BY FLOTATION PROCESS AND LEACHING
}

\author{
M. M. Ahmed ; G. A. Ibrahim \\ Mining and Metallurgical Engineering Department, Faculty of \\ Engineering, Assiut University, Assiut 71516, Egypt
}

\section{M. A. Hassan \\ Mining and Petroleum Engineering Department, Faculty of Engineering, Al-Azhar University, Qena, Egypt}

(Received October 28, 2006 Accepted November 11, 2006)

Talc is an industrial mineral that is widely used. It is always associated with other minerals, which determine the quality of talc samples for industrial purposes. Various operating variables control the natural floatability of talc. For enhancement of talc flotation, sodium hexametphosphate is used as a depressant for associated gangue minerals. In addition, oleic acid (in an equal mixture with kerosene) is used as an anionic collector. The results presented in this paper provided useful and important information on how to improve the quality of talc for industrial uses. The optimum conditions were obtained at $p H=11$, depressant dosage $=1.0 \mathrm{~kg} / \mathrm{t}$, collector dosage $=1.2 \mathrm{~kg} / \mathrm{t}$ and pulp density $=200 \mathrm{~g} / \mathrm{L}$. At these conditions, $\mathrm{SiO}_{2}$ assay increased from $54.10 \%$ to $54.94 \%, \mathrm{MgO}$ assay increased from $29.90 \%$ to $31.76 \%$, CaO decreased from $0.80 \%$ to $0.42 \%, \mathrm{Al}_{2} \mathrm{O}_{3}$ decreased from $5.50 \%$ to $3.11 \%, \mathrm{Fe}_{2} \mathrm{O}_{3}$ decreased from $8.20 \%$ to $7.24 \%$, the whiteness increased from $75.4 \%$ to $83.7 \%$, and the loss on ignition decreased from $6.64 \%$ to $5.21 \%$. The mass recovery of final concentrate was $92.4 \%$. The component recoveries of $\mathrm{SiO}_{2}$ and $\mathrm{MgO}$ (the major constituents of talc) in the final concentrate were $93.8 \%$ and $98.2 \%$, respectively. More improvement of talc quality was obtained by leaching of final concentrate of flotation with $10 \%$ dilute hydrochloric acid. The mass recovery of final product was about $85 \%$ of initial feed. In this final product, $\mathrm{Fe}_{2} \mathrm{O}_{3}$ decreased to $3.12 \%, \mathrm{CaO}$ decreased to $0.38 \%$, and $\mathrm{Al}_{2} \mathrm{O}_{3}$ decreased to $3.01 \%$. The assay of $\mathrm{SiO}_{2}$ increased to $58.96 \%, \mathrm{MgO}$ percent was nearly the same, the whiteness increased to $88.5 \%$, and the loss on ignition decreased to $4.03 \%$. The final product is suitable for many industrial uses such as low-loss electronics (a type of ceramics), paints, rubber, plastics, roofing, textiles, refractories, insecticides and coating of welding rods.

KEYWARDS: Talc, flotation, pH, depressant, collector, pulp density, sodium hexametphosphate, oleic acid, leaching, industrial purposes. 


\section{NOMENCLATURE}

$\begin{array}{lll}\mathrm{C} & = & \text { direct mass of concentrate, } \mathrm{g} \\ \mathrm{T} & = & \text { direct mass of tailings, } \mathrm{g} \\ \mathrm{F} & = & \text { direct mass of feed, } \mathrm{g} \\ \mathrm{c} & = & \text { assay of constituent in concentrate, } \% \\ \mathrm{t} & = & \text { assay of constituent in tailings, } \% \\ \mathrm{f} & = & \text { assay of constituent in feed, } \% \\ \mathrm{R}_{\mathrm{m}}(\mathrm{c}) & = & \text { mass recovery of concentrate, } \% \\ \mathrm{R}_{\mathrm{m}}(\mathrm{t}) & = & \text { mass recovery of tailings, } \% \\ \mathrm{R}_{\mathrm{c}}(\mathrm{c}) & = & \text { component recovery of concentrate, } \% \\ \mathrm{R}_{\mathrm{c}}(\mathrm{t}) & = & \text { component recovery of tailings, } \%\end{array}$

\section{INTRODUCTION}

Talc is an industrial mineral, which is composed of hydrated magnesium sheetsilicates with theoretical formula of $\mathrm{Mg}_{3} \mathrm{Si}_{4} \mathrm{O}_{10}(\mathrm{OH})_{2}$ that belongs to the phyllosilicate family [1-4]. It consists of a two dimensional sheet structure forming two layers of silica tetrahedral held together with octahedral brucite, $\mathrm{Mg}(\mathrm{OH})_{2}$ [5]. The talc surface is comprised of two types of surface area, the basal cleavage faces and the edges. The faces surface has no charged group therefore, it is believed that the talc faces are nonpolar and hydrophobic, whereas the edges are hydrophilic due to the presence of charged ions $\left(\mathrm{Mg}^{2+}\right.$ and $\left.\mathrm{OH}^{-}\right)$[5-6]. The major gangue minerals of talc are carbonates, magnesite, dolomite, serpentine, chlorite and calcite, which contribute to production of undesirable characteristics. The trace minerals including magnetite, pyrite, quartz and tremolite [7-11]. The percentage of some constituents in talc such as calcium oxide, iron oxide and aluminum oxide determine the quality of talc samples for market demands [1]. Talc is used in many industries such as paints, paper, plastic, polymers, rubbers, fertilizers, insecticides, ceramics and cosmetics [1,12-16]. Concentrating tables are used to remove high-gravity products containing nickel, cobalt and iron minerals. Flotation, magnetic separation and a combination of froth flotation and highintensity magnetic separation may be applied for the removal of iron bearing minerals [9,17-20]. Flotation is the preferred concentration technique to remove impurities $[4,19]$. Various factors that control the flotation of talc including particle size, $\mathrm{pH}$, collector dosage, depressant dosage, pulp density and frother dosage were studied by many authors $[2,9,19,21-23]$. Chemical treatments using acids may be applied to further increase the grade of concentrate. The basis of the proposed technique is the fact that talc is inert in most chemical reagents. Depurated talc minerals were leached with HCL solution. Some deficiencies may be corrected to satisfy industrial requirement. The iron content may be reduced but the economic feasibility of this treatment may be evaluated by assessing the balance between the operating costs and the price difference of products [7]. In another research, the iron content can be decreased or removed by treating the final concentrate with a dilute hydrochloric acid having a concentration of $(10 \%)$ and $\mathrm{SnCl}_{2}(300 \mathrm{ppm})$. In this case, the final product was suitable for different industrial purposes like paper, cosmetics, paints, plastics and rubbers [9]. The purpose of this paper is to determine the optimum conditions of flotation process and the possibility of using leaching to improve the quality of talc to 
be suitable for industrial purposes such as low-loss electronics (a type of ceramics), paints, rubber, plastics, roofing, textiles, refractories, insecticides and coating of welding rods [14].

\section{EXPERIMENT}

\section{Materials}

\section{Talc ore sample}

The sample used in the present work was obtained by mixing of different samples obtained from Shalatin area. Petrographically, the talc samples were classified into five different types. From the geochemical point of view, the samples were classified into three groups. This work is interested with the second group. The details and characteristics of these samples and groups were discussed in a previous published paper [1]. The final sample was crushed to minus $35 \mathrm{~mm}$ in a semi-industrial jaw crusher, then to minus $4.75 \mathrm{~mm}$ in a laboratory jaw crusher. A wet attrition scrubbing was used because the friable nature of talc. A wet attrition scrubbing conditions were as follow: pulp density $=50 \%$, motor speed $=1720 \mathrm{rpm}$ and attrition time $=45$ minutes. A particle size of minus $75 \mu \mathrm{m}$ (the desired size for flotation process) was obtained from the attrition process [19]. The final product was collected, filtered and dried. The chemical analysis of the studied head sample is given in Table 1. The particle size distribution of the flotation feed is shown in Table 2.

Table 1: Chemical analysis of the studied head sample.

\begin{tabular}{|c|c|c|c|c|c|c|c|c|c|}
\hline \multicolumn{10}{|c|}{ Assay ( $\left.\mathbf{A}_{\mathbf{f}}\right)$, \% } \\
\hline $\mathrm{SiO}_{2}$ & $\mathrm{MgO}$ & $\mathrm{CaO}$ & $\mathrm{Al}_{2} \mathrm{O}_{3}$ & $\mathrm{Fe}_{2} \mathrm{O}_{3}$ & $\mathrm{P}_{2} \mathrm{O}_{5}$ & $\mathrm{Na}_{2} \mathrm{O}$ & $\mathrm{K}_{2} \mathrm{O}$ & $\mathrm{MnO}$ & $\mathrm{SO}_{3}$ \\
\hline 54.10 & 29.90 & 0.80 & 5.50 & 8.20 & 0.52 & 0.12 & 0.15 & 0.16 & 0.43 \\
\hline
\end{tabular}

Table 2: The particle size distribution of the flotation feed.

\begin{tabular}{|c|c|c|}
\hline Size fraction, $\boldsymbol{\mu m}$ & wt. ret., $\%$ & cum. wt. ret., $\%$ \\
\hline$-75+53$ & 10.0 & 10.0 \\
\hline$-5.3+45$ & 42.0 & 52.0 \\
\hline$-45+38$ & 8.0 & 60.0 \\
\hline-38 & 40.0 & 100.0 \\
\hline$\sum$ & 100.0 & \\
\hline
\end{tabular}

\section{Reagents}

The flotation tests were carried out using oleic acid (in an equal mixture with kerosene) as a pure collector for analysis (iodine value 85-95, acid value 196-204 and molecular weight 282.47). The dosage was varied from 0.6 to $1.4 \mathrm{~kg} / \mathrm{t}$ [19]. Sodium hexametaphosphate (SHMP) were employed as a selective depressant of carbonates. It was changed from 0.4 to $1.2 \mathrm{~kg} / \mathrm{t}[19,27,28]$. The frother agent used for all tests was pine oil (a dosage of $0.1 \mathrm{~kg} / \mathrm{t}$ ). Sodium hydroxide and hydrochloric acid (30\%-34\%) are used to adjust the $\mathrm{pH}$ of the medium. Tap water is used to maintain the flotation pulp level and for all other experimental purposes. 


\section{Apparatus}

Laboratory flotation tests were carried out in a $2800 \mathrm{~cm}^{3}$ Wemco Fagergren cell. A water perspex tank was used to maintain the pulp level at a constant value. Hand skimming was used to collect the froth overflow.

\section{Procedure}

All flotation tests were carried out at room temperature. The impeller speed was fixed at $1100 \mathrm{rpm}$ and an aeration rate of $6 \mathrm{~L} / \mathrm{min}$ was used. The total conditioning time was $10 \mathrm{~min}$. The talc sample was added slowly and conditioned with water for five min. Further water was then added to bring the liquid level to the required $10 \mathrm{~mm}$ below the overflow lip. The $\mathrm{pH}$ modifiers were added to adjust the required $\mathrm{pH}$. The depressant dosage sodium hexametaphosphate (SHMP) was added at the end of the initial conditioning period and was allowed to condition for $2 \mathrm{~min}$. with the pulp. The collector dosage (oleic acid and kerosene mixture) was added at the end of the previous period and was allowed to condition for $2 \mathrm{~min}$. with the pulp. The frother dosage was then added and a further $1 \mathrm{~min}$. of conditioning was allowed prior to aeration. The air supply was gradually opened. The required pulp level was maintained constant.

In each experiment, after allowing 15 seconds for froth to form, a hand skimmer was used to collect the froth over until the froth is stopped. After the process being finished, the products (concentrate and tailings) were dried, weighed and chemically analyzed. The experimental part of this paper was done in the ore dressing laboratories of the Mining and Metallurgical Department, Faculty of Engineering, Assuit University.

\section{RESULTS AND DISCUSSION}

\section{Calculations of Experimental Mass and Component Recoveries of Flotation Products}

Using the direct mass percent and assays of different constituents of the feed, concentrate, and tailings, the experimental values of the mass and component recoveries of the flotation products can be calculated as follows:

$$
\begin{aligned}
& \text { Mass recovery of concentrat } e=R_{m}(c)=100 \cdot \frac{C}{F} \\
& \text { Mass recovery of tailings }=R_{m}(t)=100 \cdot \frac{T}{F} \\
& \text { Component recovery of concentrat } e=R_{c}(c)=100 \cdot \frac{C \cdot c}{F . f} \\
& \text { Component recovery of tailings }=R_{c}(t)=100 \cdot \frac{T \cdot t}{F . f}
\end{aligned}
$$

\section{Effect of pH}

Table $3 \mathbf{a}$ includes the chemical analysis of constituents in flotation products of experiments carried out at different $\mathrm{pH}$ values. This table showed that the percentages of $\mathrm{SiO}_{2}$ and $\mathrm{MgO}$ (the major constituents of talc) decreased in the concentrate product 
with increasing $\mathrm{pH}$ value from 4 to 12 . Conversely, the percentages of $\mathrm{CaO}, \mathrm{Al}_{2} \mathrm{O}_{3}$ and $\mathrm{Fe}_{2} \mathrm{O}_{3}$ (the main wastes in talc) increased. These results are illustrated also in Figures 1a through 1e. From Figures $\mathbf{1 a}$ and $\mathbf{1 b}$, it can be seen that, the $\mathrm{SiO}_{2}$ assay decreased from $\mathrm{pH} 4$ to $\mathrm{pH} 12(57.02 \%$ to $54.30 \%)$, as well as, $\mathrm{MgO}$ assay decreased from $\mathrm{pH} 4$ to $\mathrm{pH} 12(34.0 \%$ to $31.8 \%)$. This may be interpreted due to the tendency of magnesium to precipitate or hydrolysis with increasing $\mathrm{pH}$, which leads to decrease its content, especially at the alkaline values [24-25].

Figures 1c through 1e showed that with increasing the value of $\mathrm{pH}$ from 4 to 12 , $\mathrm{CaO}$ increased (from $0.35 \%$ to $0.72 \%$ ), $\mathrm{Al}_{2} \mathrm{O}_{3}$ increased (from $2.17 \%$ to $4.30 \%$ ), and $\mathrm{Fe}_{2} \mathrm{O}_{3}$ increased (from $6.22 \%$ to $8.10 \%$ ). This may be attributed to that, the carbonates content increase with increasing $\mathrm{pH}$. These results are in agreement with the work of Al-Wakeel [9].

The percentage of iron oxide is still high due to the association of iron oxide with all mineral components of the sample, which sometimes appearing as yellowish brown threads along its schistose structure and in other cases, associating with the banded talc- chlorite structure [19].

The effect of $\mathrm{pH}$ values on the mass recovery of concentrate is shown in Table $\mathbf{3 b}$ and Fig. 1f. From this figure, it can be seen that, the mass recovery increased from $53 \%$ to $84.5 \%$, as the value of $\mathrm{pH}$ increased from $\mathrm{pH} 4$ to $\mathrm{pH} 11$. More increase of the $\mathrm{pH}$ value, above 11 , decreased the mass recovery.

Table 3a: The chemical analysis of constituents in flotation products of experiments carried out at different $\mathrm{pH}$ values.

\begin{tabular}{|c|c|c|c|c|c|c|c|c|c|c|c|}
\hline \multirow{3}{*}{$\begin{array}{l}\text { Exp. } \\
\text { No. }\end{array}$} & \multirow{3}{*}{ pH } & \multicolumn{5}{|c|}{ Concentrate } & \multicolumn{5}{|c|}{ Tailings } \\
\hline & & \multicolumn{5}{|c|}{$\operatorname{Assay}\left(\mathbf{A}_{c}\right), \%$} & \multicolumn{5}{|c|}{$\operatorname{Assay}\left(\mathbf{A}_{\mathbf{t}}\right), \%$} \\
\hline & & $\mathrm{SiO}_{2}$ & $\mathrm{MgO}$ & $\mathrm{CaO}$ & $\mathrm{Al}_{2} \mathrm{O}_{3}$ & $\mathrm{Fe}_{2} \mathrm{O}_{3}$ & $\mathrm{SiO}_{2}$ & $\mathrm{MgO}$ & $\mathrm{CaO}$ & $\mathrm{Al}_{2} \mathrm{O}_{3}$ & $\mathrm{Fe}_{2} \mathrm{O}_{3}$ \\
\hline 1 & 4 & 57.02 & 34.00 & 0.35 & 2.17 & 6.22 & 50.81 & 25.28 & 1.31 & 9.26 & 10.43 \\
\hline 2 & 7 & 56.15 & 33.39 & 0.42 & 2.62 & 6.53 & 50.41 & 23.61 & 1.48 & 10.69 & 11.21 \\
\hline 3 & 9 & 55.9 & 33.03 & 0.44 & 2.78 & 6.85 & 50.45 & 23.55 & 1.53 & 11.02 & 10.94 \\
\hline 4 & 11 & 55.71 & 32.92 & 0.50 & 3.03 & 7.14 & 45.32 & 13.44 & 2.44 & 18.97 & 13.98 \\
\hline 5 & 12 & 54.3 & 31.81 & 0.72 & 4.3 & 8.10 & 53.40 & 23.24 & 1.08 & 9.68 & 8.55 \\
\hline
\end{tabular}

Table 3b: The mass recoveries of flotation products and the component recoveries of constituents of experiments carried out at different $\mathrm{pH}$ values.

\begin{tabular}{|c|c|c|c|c|c|c|c|c|c|c|c|c|}
\hline \multirow{3}{*}{$\mathbf{p H}$} & \multicolumn{6}{|c|}{ Concentrate } & \multicolumn{6}{|c|}{ Tailings } \\
\hline & \multicolumn{5}{|c|}{ Component recovery $\mathbf{R}_{\mathrm{c}}(\mathrm{c}), \%$} & \multirow{2}{*}{$\begin{array}{c}\mathbf{R}_{\mathrm{m}}(\mathbf{c}), \\
\%\end{array}$} & \multicolumn{5}{|c|}{ Component recovery $R_{c}(t), \%$} & \multirow{2}{*}{$\begin{array}{c}\mathbf{R}_{\mathrm{m}}(\mathbf{t}), \\
\%\end{array}$} \\
\hline & $\mathrm{SiO}_{2}$ & $\mathrm{MgO}$ & $\mathrm{CaO}$ & $\mathrm{Al}_{2} \mathrm{O}_{3}$ & $\mathrm{Fe}_{2} \mathrm{O}_{3}$ & & $\mathrm{SiO}_{2}$ & $\mathrm{MgO}$ & $\mathrm{CaO}$ & $\mathrm{Al}_{2} \mathrm{O}_{3}$ & $\mathrm{Fe}_{2} \mathrm{O}_{3}$ & \\
\hline 4 & 55.9 & 60.3 & 23.2 & 20.9 & 40.2 & 53.0 & 44.1 & 39.7 & 76.8 & 79.1 & 59.8 & 47.0 \\
\hline 7 & 66.7 & 71.8 & 33.8 & 30.6 & 51.2 & 64.3 & 33.3 & 28.2 & 66.2 & 69.4 & 48.8 & 35.7 \\
\hline 9 & 69.2 & 74.0 & 36.9 & 33.9 & 56.0 & 67.0 & 30.8 & 26.0 & 63.1 & 66.1 & 44.0 & 33.0 \\
\hline 11 & 87.0 & 93.0 & 52.8 & 46.6 & 73.6 & 84.5 & 13.0 & 7.0 & 47.2 & 53.4 & 26.4 & 15.5 \\
\hline 12 & 78.0 & 82.7 & 69.9 & 60.7 & 76.8 & 77.7 & 22.0 & 17.3 & 30.1 & 39.1 & 23.2 & 22.3 \\
\hline
\end{tabular}




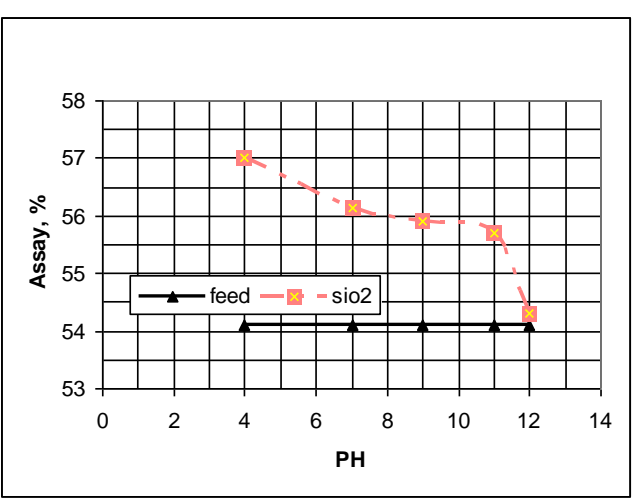

Fig. 1a: $\mathrm{SiO}_{2}$ assay with $\mathrm{pH}$.

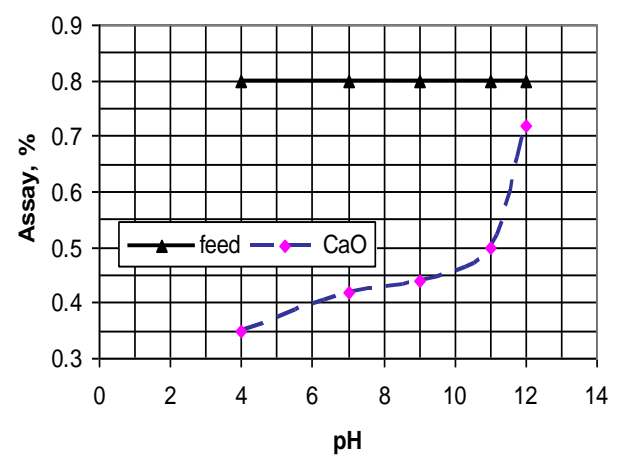

Fig. 1c: $\mathrm{CaO}$ assay with $\mathrm{pH}$.

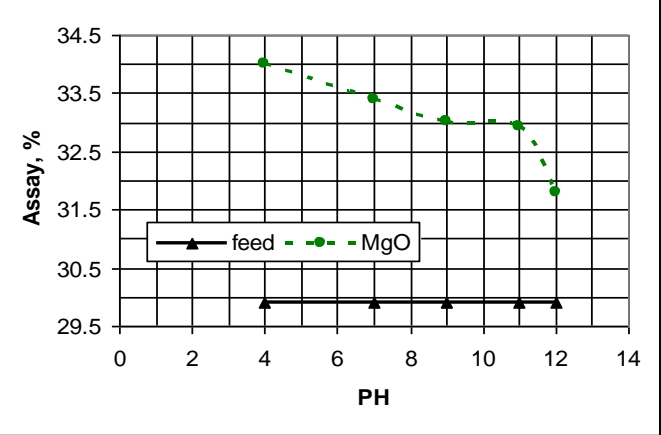

Fig. 1b: MgO assay with $\mathrm{pH}$.

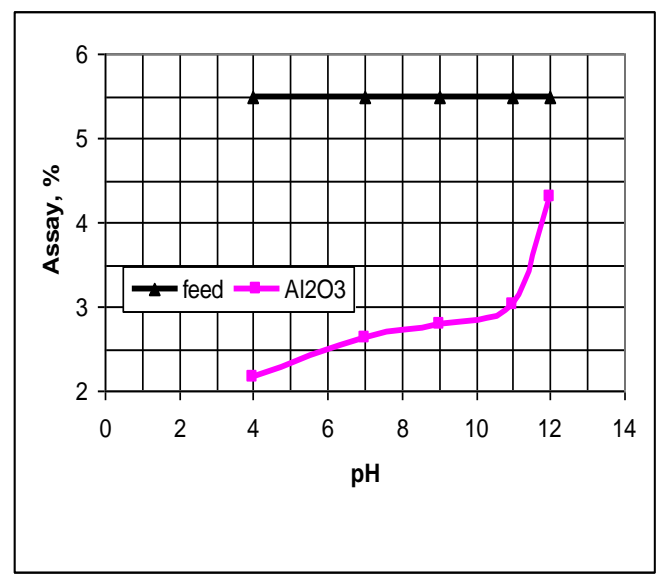

Fig. 1d: $\mathrm{Al}_{2} \mathrm{O}_{3}$ assay with $\mathrm{pH}$.

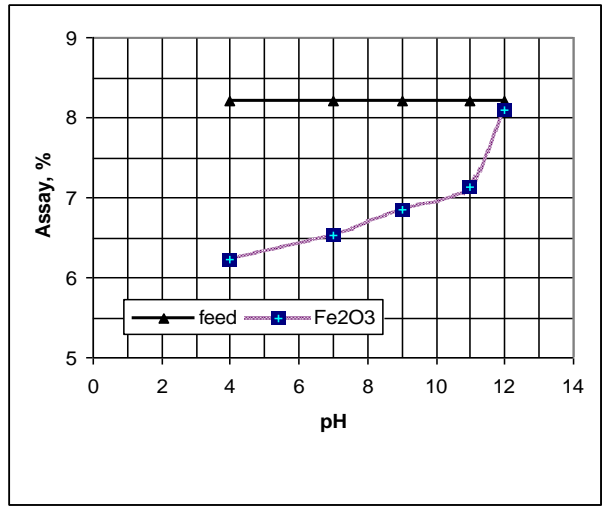

Fig. 1e: $\mathrm{Fe}_{2} \mathrm{O}_{3}$ assay with $\mathrm{pH}$.

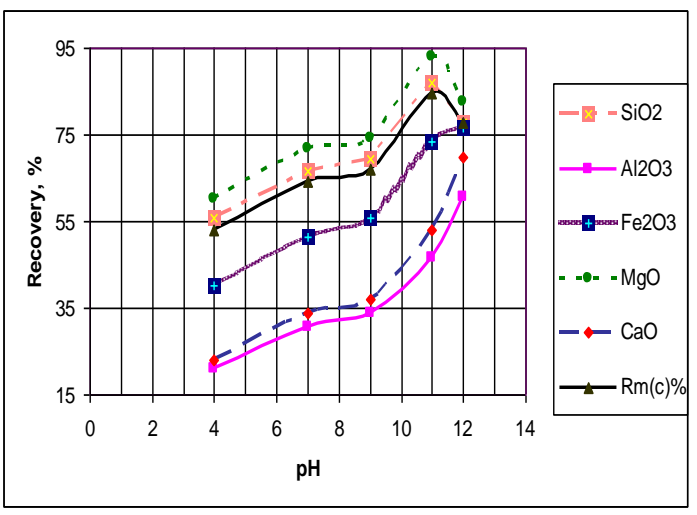

Fig. 1f: Mass and component recoveries with $\mathrm{pH}$.

Fig. 1: Effect of $\mathrm{pH}$ values on the mass recovery, as well as, on the assays and component recoveries of different constituents in concentrate. 
The effect of $\mathrm{pH}$ values on the component recoveries of constituents in concentrate is illustrated also in Table $\mathbf{3 b}$ and Fig. 1f. From this figure, it can be shown that, the component recovery of $\mathrm{SiO}_{2}$ increased from $56 \%$ to $87 \%$, as well as, the component recovery of $\mathrm{MgO}$ increased from $60 \%$ to $93 \%$ as the $\mathrm{pH}$ value increased from $\mathrm{pH} 4$ to $\mathrm{pH}$ 11. Any increase of $\mathrm{pH}$ value decreased the component recoveries of these two constituents. On the other hand, the component recoveries of $\mathrm{CaO}, \mathrm{Al}_{2} \mathrm{O}_{3}$ and $\mathrm{Fe}_{2} \mathrm{O}_{3}$ increased with increasing the $\mathrm{pH}$ value.

The above results can be interpreted such that, the hydrophobicity of talc surface increases as $\mathrm{pH}$ increases from 2 to 11 . The floatability of talc is slightly affected by increasing of $\mathrm{H}^{+}$(from $\mathrm{pH} 2$ to 7 ) and is more affected by increasing $\mathrm{OH}^{-}$(from $\mathrm{pH} 7$ to 11) [9]. The anisotropy nature of talc revealed that their crystals consist of faces, which are being hydrophobic and not charged, and edges being hydrophilic and charged. The bubbles will attach to the hydrophobic faces where they are not affected by the edge charge. At a higher $\mathrm{pH}$ value, over 11, the overall charge on the particle may give a rise to a high repulsion of air bubbles. This may be due to that some dissolution of particles takes place at high $\mathrm{pH}$ and adsorption of hydrolyzed species may contribute to increase of hydrophilicity [2]. Although the talc has a point of zero charge (ZPC) at $\mathrm{pH} 1.8$ [9], the using of oleic acid, as an anionic collector, will change zeta potential of talc from a negative to a positive value at $\mathrm{pH} 11$ [26].

From Table 3a, it can be seen that the assays of $\mathrm{SiO}_{2}$ and $\mathrm{MgO}$ were at their lowest values in tailings, as well as, the assays of $\mathrm{CaO}, \mathrm{Al}_{2} \mathrm{O}_{3}$ and $\mathrm{Fe}_{2} \mathrm{O}_{3}$ were at their highest ones at the same value of $\mathrm{pH} 11$. This assures that the optimum conditions of these experiments can be obtained at $\mathrm{pH} 11$.

\section{Effect of Depressant Dosage}

Table 4a contains the chemical analysis of constituents in flotation products of experiments executed at different depression dosages of sodium hexametaphosphate (SHMP). The table showed that the percentages of $\mathrm{SiO}_{2}$ and $\mathrm{MgO}$ (the major constituents of talc) decreased in the concentrate product with increasing the depression dosage from 0.4 to $1.2 \mathrm{~kg} / \mathrm{t}$. Conversely, the percentages of $\mathrm{CaO}, \mathrm{Al}_{2} \mathrm{O}_{3}$ and $\mathrm{Fe}_{2} \mathrm{O}_{3}$ (the main wastes in talc) increased. These results are also revealed in Figures $\mathbf{2 a}$ through $\mathbf{2 e}$. From Figures $\mathbf{2 a}$ and $\mathbf{2 b}$, it can be seen that, $\mathrm{SiO}_{2}$ decreased (from $57.23 \%$ to $54.46 \%$ ) with increasing the depression dosage from 0.4 to $1.2 \mathrm{~kg} / \mathrm{t}$, as well as $\mathrm{MgO}$ decreased (from $34.13 \%$ to $31.29 \%$ ) with the same dosage.

Figure 2c shows that $\mathrm{CaO}$ decreased (from $0.72 \%$ to $0.42 \%$ ) if the depression dosage was increased from $0.4 \mathrm{Kg} / \mathrm{t}$ to $1.0 \mathrm{Kg} / \mathrm{t}$. More increasing of the dosage will lead to increase the final percent of $\mathrm{CaO}$. This trend can be explained due to the ability of sodium hexametaphosphate (SHMP) to sequester the calcium cations $\left(\mathrm{Ca}^{2+}\right)$ and forming with the calcium a strong hydrophilic complex compound [27-28]. Figures $\mathbf{2} \mathbf{d}$ and $\mathbf{2 e}$ showed that with increasing the depression dosage from 0.4 to 1.2 $\mathrm{kg} / \mathrm{t}, \mathrm{Al}_{2} \mathrm{O}_{3}$ increased (from $1.98 \%$ to $4.21 \%$ ), as well as $\mathrm{Fe}_{2} \mathrm{O}_{3}$ increased (from $5.88 \%$ to $8.07 \%$ ). This may be interpreted to the interaction of sodium hexametaphosphate (SHMP) anions with the exposed atoms of $\mathrm{Al}$ giving complexed anions but the action of sodium hexametaphosphate towards aluminum is a weak to sequester the aluminum sites [27]. 
Table 4a: The chemical analysis of constituents in flotation products of experiments carried out at different depression dosages.

\begin{tabular}{|c|c|c|c|c|c|c|c|c|c|c|c|}
\hline \multirow{2}{*}{$\begin{array}{c}\text { Exp. } \\
\text { No. }\end{array}$} & \multirow{2}{*}{$\begin{array}{c}\text { Depression } \\
\text { dosage, } \\
\mathbf{k g} / \mathbf{t}\end{array}$} & \multicolumn{4}{|c|}{ Concentrate } & \multicolumn{5}{c|}{ Aailings } \\
\cline { 3 - 12 } & & $\mathrm{SiO}_{2}$ & $\mathrm{MgO}$ & $\mathrm{CaO}$ & $\mathrm{Al}_{2} \mathrm{O}_{3}$ & $\mathrm{Fe}_{2} \mathrm{O}_{3}$ & $\mathrm{SiO}_{2}$ & $\mathrm{MgO}$ & $\mathrm{CaO}$ & $\mathrm{Al}_{2} \mathrm{O}_{3}$ & $\mathrm{Fe}_{2} \mathrm{O}_{3}$ \\
\hline 1 & 0.4 & 57.23 & 34.13 & 0.72 & 1.98 & 5.88 & 46.36 & 19.44 & 1.00 & 14.20 & 13.94 \\
\hline 2 & 0.6 & 56.57 & 33.67 & 0.63 & 2.14 & 6.35 & 45.59 & 16.91 & 1.39 & 17.07 & 14.57 \\
\hline 3 & 0.8 & 55.71 & 32.92 & 0.50 & 3.03 & 7.14 & 45.32 & 13.44 & 2.44 & 18.97 & 13.98 \\
\hline 4 & 1.0 & 54.97 & 31.89 & 0.42 & 3.08 & 7.21 & 41.36 & 15.31 & 3.59 & 23.25 & 15.46 \\
\hline 5 & 1.2 & 54.46 & 31.29 & 0.68 & 4.21 & 8.07 & 52.96 & 25.5 & 1.18 & 9.59 & 8.61 \\
\hline
\end{tabular}

Table 4b: The mass recoveries of flotation products and the component recoveries of constituents of experiments executed at different depression dosages.

\begin{tabular}{|c|c|c|c|c|c|c|c|c|c|c|c|c|}
\hline \multirow{3}{*}{$\begin{array}{c}\text { Depression } \\
\text { dosage, } \\
\mathrm{kg} / \mathrm{t}\end{array}$} & \multicolumn{6}{|c|}{ Concentrate } & \multicolumn{6}{|c|}{ Tailings } \\
\hline & \multicolumn{5}{|c|}{ Component recovery $\mathbf{R}_{\mathrm{c}}(\mathbf{c}), \%$} & \multirow{2}{*}{$\begin{array}{c}R_{\mathrm{m}}(\mathbf{c}), \\
\%\end{array}$} & \multicolumn{5}{|c|}{ Component recovery $R_{c}(t), \%$} & \multirow{2}{*}{$\begin{array}{c}\mathbf{R}_{\mathrm{m}}(\mathbf{t}), \\
\%\end{array}$} \\
\hline & $\mathrm{SiO}_{2}$ & $\mathrm{MgO}$ & $\mathrm{CaO}$ & $\mathrm{Al}_{2} \mathrm{O}_{3}$ & $\mathrm{Fe}_{2} \mathrm{O}_{3}$ & & $\mathrm{SiO}_{2}$ & $\mathrm{MgO}$ & $\mathrm{CaO}$ & $\mathrm{Al}_{2} \mathrm{O}_{3}$ & $\mathrm{Fe}_{2} \mathrm{O}_{3}$ & \\
\hline 0.4 & 75.3 & 81.3 & 64.0 & 25.6 & 51.1 & 71.2 & 24.7 & 18.7 & 36.0 & 74.4 & 48.9 & 28.8 \\
\hline 0.6 & 81.0 & 87.3 & 61.0 & 30.2 & 60.0 & 77.5 & 19.0 & 12.7 & 39.0 & 69.8 & 40.0 & 22.5 \\
\hline 0.8 & 87.0 & 93.0 & 52.8 & 46.6 & 73.6 & 84.5 & 13.0 & 7.0 & 47.2 & 53.4 & 26.4 & 15.5 \\
\hline 1.0 & 89.4 & 93.9 & 46.2 & 49.3 & 77.4 & 88.0 & 10.6 & 6.1 & 53.8 & 50.7 & 22.6 & 12.0 \\
\hline 1.2 & 76.5 & 79.5 & 64.6 & 58.2 & 74.8 & 76.0 & 23.5 & 20.5 & 35.4 & 41.8 & 25.2 & 24.0 \\
\hline
\end{tabular}

The effect of depression dosages on the mass recovery of concentrate is shown in Table $\mathbf{4 b}$ and Fig. 2f. From this figure, it can be seen that, the mass recovery increased from $71.2 \%$ to $88.0 \%$, as the value of depression dosage increased from 0.4 to $1.0 \mathrm{~kg} / \mathrm{t}$. More increase of the depression dosage, above $1.0 \mathrm{~kg} / \mathrm{t}$, decreased the mass recovery. The effect of depression dosages on the component recoveries of constituents in concentrate is illustrated also in Table $\mathbf{4 b}$ and Fig. 2f. From this figure, it can be seen that, the component recovery of $\mathrm{SiO}_{2}$ increased (from $75.3 \%$ to $89.4 \%$ ), as well as, the component recovery of $\mathrm{MgO}$ increased (from $81.3 \%$ to $93.9 \%$ ) as the depression dosage increased from 0.4 to $1.0 \mathrm{~kg} / \mathrm{t}$. Any increase of depression dosage above this value decreased the component recoveries of these two constituents. From Fig. 2f, it can be also revealed that the component recovery of $\mathrm{CaO}$ decreased (from $64.0 \%$ to $46.2 \%$ ) as the depression dosage increased from 0.4 to $1.0 \mathrm{~kg} / \mathrm{t}$ and then increased by increasing of depression dosage above $1.0 \mathrm{~kg} / \mathrm{t}$. On the other hand, the component recoveries of $\mathrm{Al}_{2} \mathrm{O}_{3}$ and $\mathrm{Fe}_{2} \mathrm{O}_{3}$ increased with increasing the depression dosage value.

From Table 4a, it can be seen that the assays of $\mathrm{SiO}_{2}$ and $\mathrm{MgO}$ were at their lowest values in tailings, as well as, the assays of $\mathrm{CaO}, \mathrm{Al}_{2} \mathrm{O}_{3}$ and $\mathrm{Fe}_{2} \mathrm{O}_{3}$ were at their highest ones at the same value of depression dosage $(1.0 \mathrm{~kg} / \mathrm{t})$. This assures that the optimum conditions of these experiments may be obtained at a depression dosage of $1.0 \mathrm{~kg} / \mathrm{t}$. 


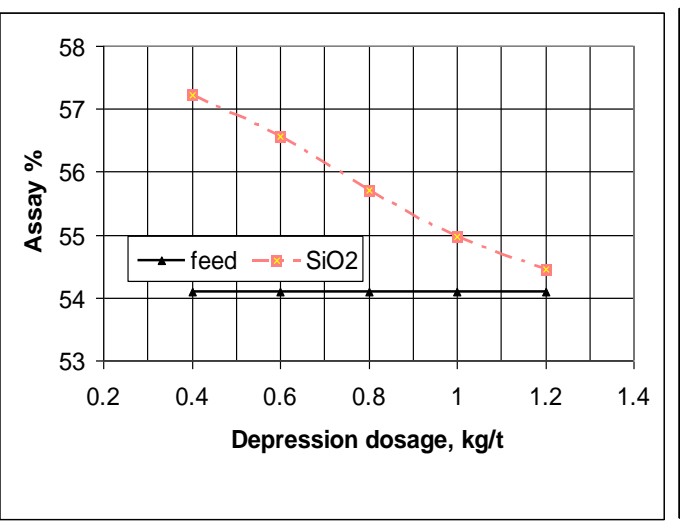

Fig. 2a: $\mathrm{SiO}_{2}$ assay with depression dosage

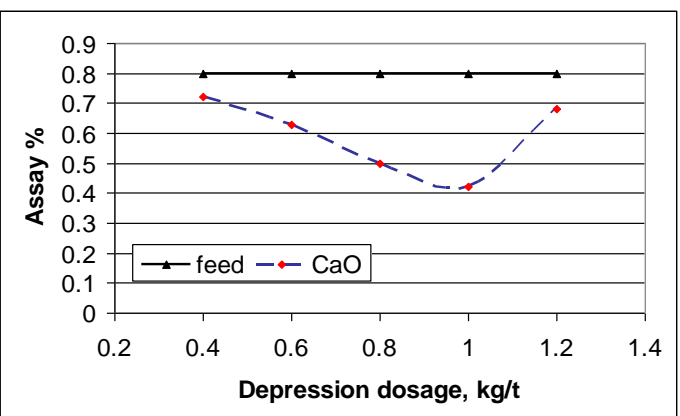

Fig. 2c: $\mathrm{CaO}$ assay with depression dosage

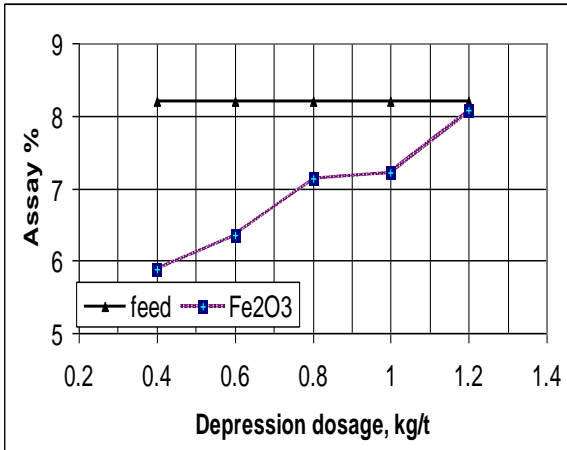

Fig. 2e: $\mathrm{Fe}_{2} \mathrm{O}_{3}$ assay with depression dosage

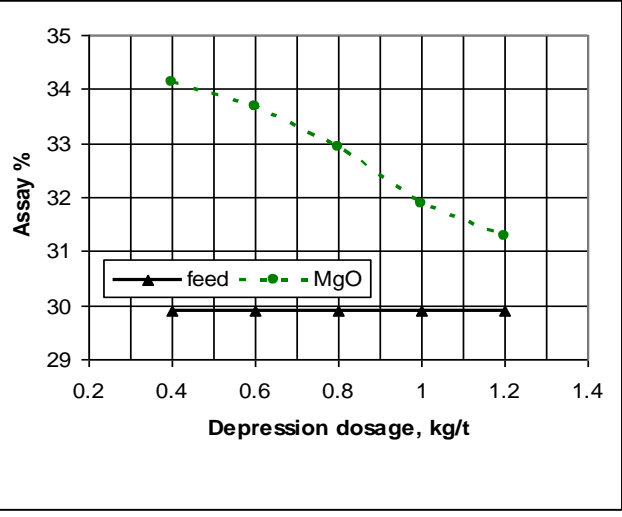

Fig. 2b: $\mathrm{MgO}$ assay with depression dosage

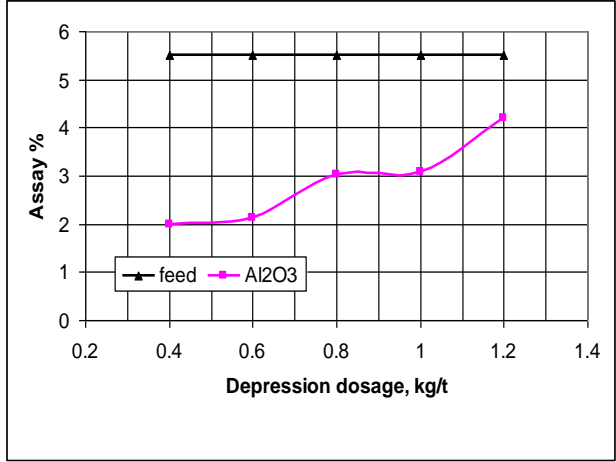

Fig. 2d: $\mathrm{Al}_{2} \mathrm{O}_{3}$ assay with depression dosage

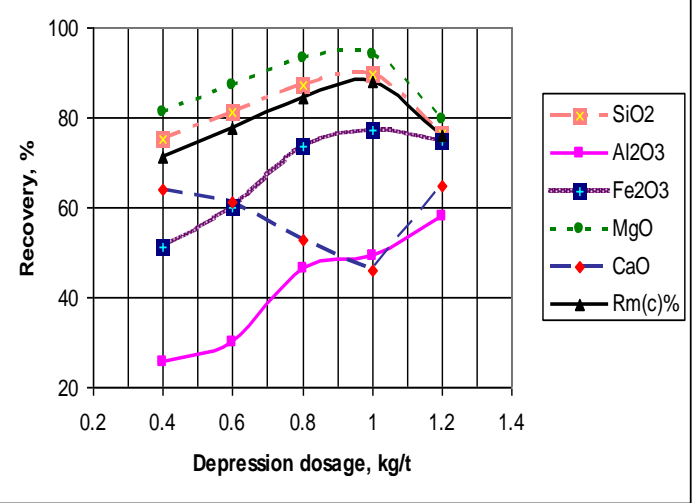

Fig. 2f: Mass and component recoveries with depression dosage

Fig. 2: Effect of depression dosage on the mass recovery, as well as, on the assays and component recoveries of different constituents in concentrate 


\section{Effect of Collector Dosage}

Table 5a included the chemical analysis of constituents in flotation products of experiments carried out at different collector dosages of oleic acid (in an equal mixture with kerosene). The table showed that the percentages of $\mathrm{SiO}_{2}$ and $\mathrm{MgO}$ (the major constituents of talc) decreased in the concentrate product with increasing the collector dosage from 0.6 to $1.4 \mathrm{~kg} / \mathrm{t}$. Conversely, the percentages of $\mathrm{CaO}, \mathrm{Al}_{2} \mathrm{O}_{3}$ and $\mathrm{Fe}_{2} \mathrm{O}_{3}$ (the main wastes in talc) increased. These results are illustrated also in Figures $\mathbf{3 a}$ through 3e. From Figures $\mathbf{3 a}$ and $\mathbf{3 b}$, it can be shown that, $\mathrm{SiO}_{2}$ decreased (from $57.46 \%$ to $54.15 \%)$ at increasing of the collector dosage from 0.6 to $1.4 \mathrm{~kg} / \mathrm{t}$, as well as $\mathrm{MgO}$ decreased (from $34.22 \%$ to $30.69 \%$ ) at the same collector dosage. This may be attributed to the powerful of oleic acid (anionic collector) to produce a water-repulsion and monomolecular layer on particle surfaces (starvation level), thereby imparting hydrophobicity to the particles [29].

Figures $\mathbf{3} \mathbf{c}$ through $\mathbf{3 e}$ showed that as the collector dosage increased from 0.6 to $1.4 \mathrm{~kg} / \mathrm{t}, \mathrm{CaO}$ increased (from $0.30 \%$ to $0.54 \%$ ), $\mathrm{Al}_{2} \mathrm{O}_{3}$ increased (from $2.09 \%$ to $3.95 \%$ ), and $\mathrm{Fe}_{2} \mathrm{O}_{3}$ increased (from 5.90\% to 7.97).

The effect of collector dosages on the mass recovery of concentrate is shown in Table 5b and Fig. 3f. From this figure, it can be revealed that, the mass recovery increased from $72.1 \%$ to $92.4 \%$, as the collector dosage increased from 0.6 to $1.2 \mathrm{~kg} / \mathrm{t}$. More increase of the collector dosage above $1.2 \mathrm{~kg} / \mathrm{t}$ decreased the mass recovery.

Table 5a: The chemical analysis of constituents in flotation products of experiments carried out at different collector dosages.

\begin{tabular}{|c|c|c|c|c|c|c|c|c|c|c|c|}
\hline \multirow{3}{*}{$\begin{array}{c}\text { Exp. } \\
\text { No. }\end{array}$} & \multirow{3}{*}{$\begin{array}{c}\text { Collector } \\
\text { dosage, } \\
\mathrm{kg} / \mathrm{t}\end{array}$} & \multicolumn{5}{|c|}{ Concentrate } & \multicolumn{5}{|c|}{ Tailings } \\
\hline & & \multicolumn{5}{|c|}{$\operatorname{Assay}\left(\mathbf{A}_{\mathbf{c}}\right), \%$} & \multicolumn{5}{|c|}{$\operatorname{Assay}\left(\mathbf{A}_{\mathrm{t}}\right), \%$} \\
\hline & & $\mathrm{SiO}_{2}$ & $\mathrm{MgO}$ & $\mathrm{CaO}$ & $\mathrm{Al}_{2} \mathrm{O}_{3}$ & $\mathrm{Fe}_{2} \mathrm{O}_{3}$ & $\mathrm{SiO}_{2}$ & $\mathrm{MgO}$ & $\mathrm{CaO}$ & $\mathrm{Al}_{2} \mathrm{O}_{3}$ & $\mathrm{Fe}_{2} \mathrm{O}_{3}$ \\
\hline 1 & 0.6 & 57.46 & 34.22 & 0.30 & 2.09 & 5.90 & 45.42 & 18.74 & 2.09 & 14.31 & 14.14 \\
\hline 2 & 0.8 & .78 & 32.83 & 0. & 2.7 & 6.78 & 47.16 & 17.80 & 2.62 & 16.85 & 14.06 \\
\hline 3 & .0 & 4.97 & 31.89 & 0.42 & 3.08 & 7.21 & 41.36 & 15.31 & 3.59 & 23.25 & 15.46 \\
\hline 4 & 1.2 & 54.94 & 31.76 & 0.42 & 3.11 & 7.24 & 41.35 & 7.29 & 5.42 & 24.20 & 19.87 \\
\hline 5 & 1.4 & 54.15 & 30.69 & 0.54 & 3.95 & 7.97 & 49.13 & 24.98 & 2.14 & 13.52 & 8.05 \\
\hline
\end{tabular}

Table 5b: The mass recoveries of flotation products and the component recoveries of constituents of experiments carried out at different collector dosages.

\begin{tabular}{|c|c|c|c|c|c|c|c|c|c|c|c|c|}
\hline \multirow{3}{*}{$\begin{array}{c}\text { Collector } \\
\text { dosage, } \\
\mathrm{kg} / \mathrm{t}\end{array}$} & \multicolumn{6}{|c|}{ Concentrate } & \multicolumn{6}{|c|}{ Tailings } \\
\hline & \multicolumn{5}{|c|}{ Component recovery $\mathbf{R}_{c}(\mathbf{c}), \%$} & \multirow{2}{*}{$\begin{array}{c}\mathbf{R}_{\mathrm{m}} \\
\text { (c),\% }\end{array}$} & \multicolumn{5}{|c|}{ Component recovery $\mathbf{R}_{\mathrm{c}}(\mathrm{t}), \%$} & \multirow{2}{*}{$\begin{array}{c}\mathbf{R}_{\mathrm{m}}(\mathbf{t}), \\
\%\end{array}$} \\
\hline & $\mathrm{SiO}_{2}$ & $\mathrm{MgO}$ & $\mathrm{CaO}$ & $\mathrm{Al}_{2} \mathrm{O}_{3}$ & $\mathrm{Fe}_{2} \mathrm{O}_{3}$ & & $\mathrm{SiO}_{2}$ & $\mathrm{MgO}$ & $\mathrm{CaO}$ & $\mathrm{Al}_{2} \mathrm{O}_{3}$ & $\mathrm{Fe}_{2} \mathrm{O}_{3}$ & \\
\hline 0.6 & 76.6 & 82.5 & 27.0 & 27.4 & 51.9 & 72.1 & 23.4 & 17.5 & 73.0 & 72.6 & 48.1 & 27.9 \\
\hline 0.8 & 83.0 & 88.4 & 36.2 & 40.3 & 66.6 & 80.5 & 17.0 & 11.6 & 63.8 & 59.7 & 33.4 & 19.5 \\
\hline 1.0 & 89.4 & 93.9 & 46.2 & 49.3 & 77.4 & 88.0 & 10.6 & 6.1 & 53.8 & 50.7 & 22.6 & 12.0 \\
\hline 1.2 & 93.8 & 98.2 & 48.5 & 52.3 & 81.6 & 92.4 & 6.2 & 1.8 & 51.5 & 47.7 & 18.4 & 7.6 \\
\hline 1.4 & 83.9 & 86.0 & 56.6 & 60.2 & 81.5 & 83.8 & 16.1 & 14.0 & 43.4 & 39.8 & 18.5 & 16.2 \\
\hline
\end{tabular}



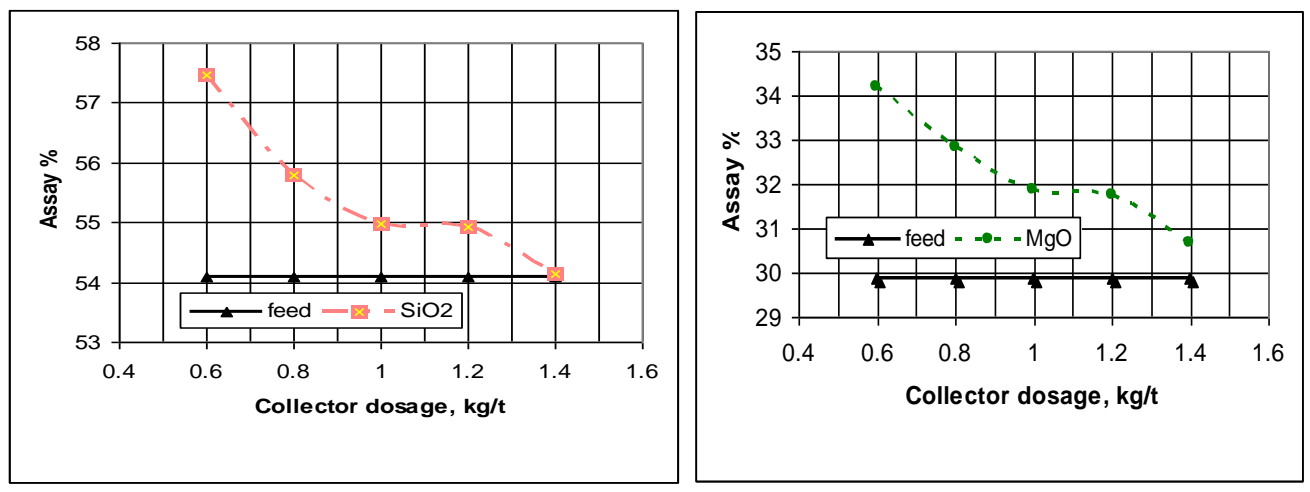

Fig. 3a: $\mathrm{SiO}_{2}$ assay with collector dosage. Fig. 3b: $\mathrm{MgO}$ assay with collector dosage
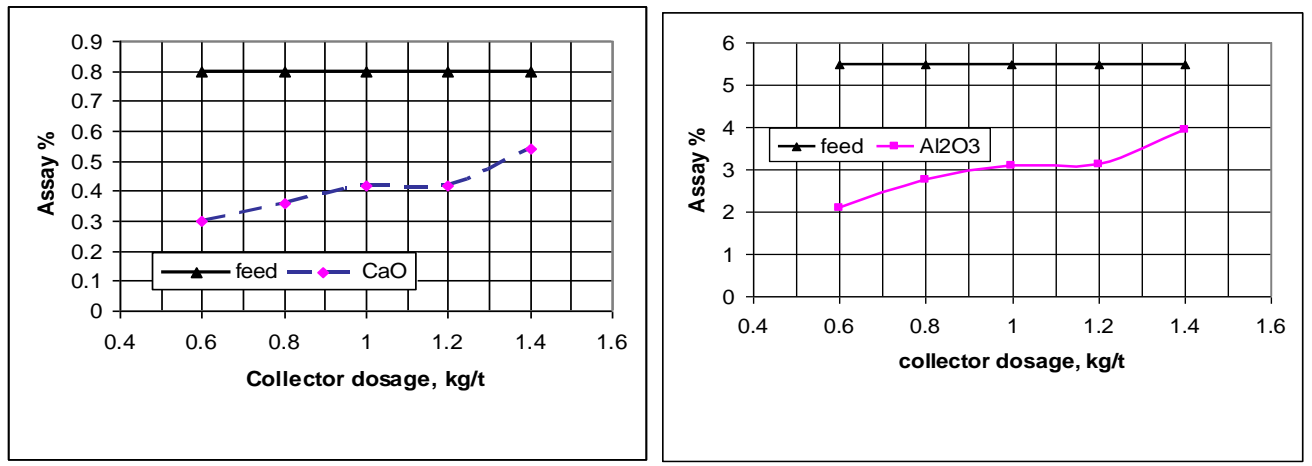

Fig. 3c: $\mathrm{CaO}$ assay with collector dosage. Fig. 3 d: $\mathrm{Al}_{2} \mathrm{O}_{3}$ assay with collector dosage.

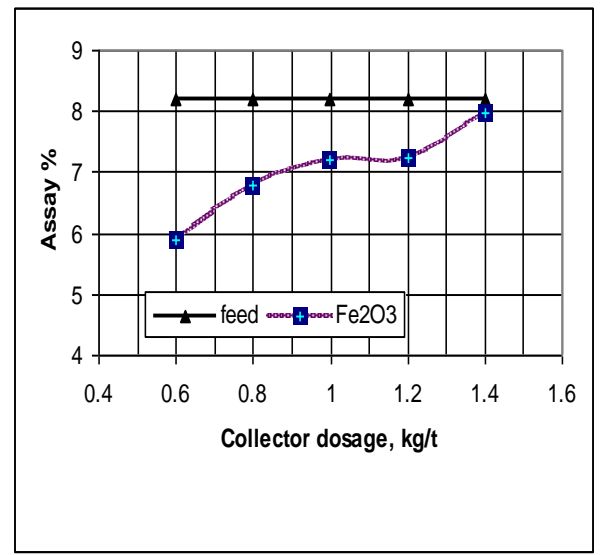

Fig. 3e: $\mathrm{Fe}_{2} \mathrm{O}_{3}$ assay with collector dosage.

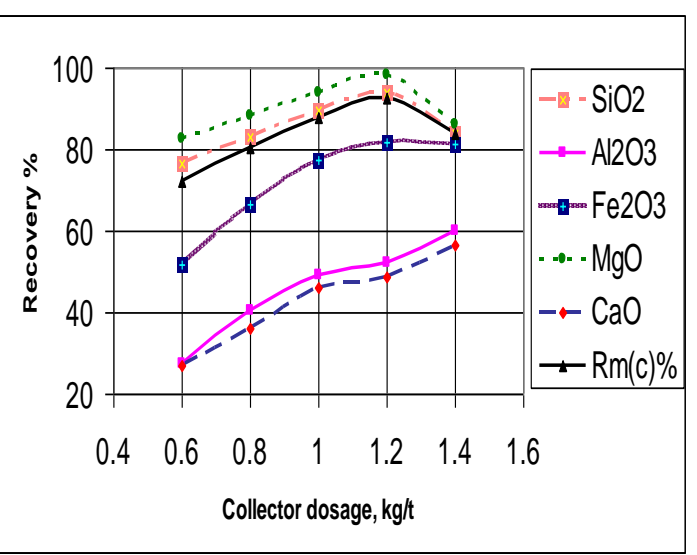

Fig. 3f: Mass and component recoveries with collector dosage.

Fig. 3: Effect of collector dosage on the mass recovery, as well as, on the assays and component recoveries of different constituents in concentrate. 
The increase of the flotation recovery with the collector dosage may be explained due to the more rapid reaction at higher concentration or due to more rapid approach of the exchanger adsorption equilibrium at higher concentration. This trend can be explained also due to the displacement of the exchange-adsorption equilibrium more and more toward complete collector adsorption as concentration of the collector is increased [30]. The effect of collector dosages on the component recoveries of constituents in concentrate are illustrated also in Table $\mathbf{5 b}$ and Fig. 3f. From this figure, it can be shown that, the component recovery of $\mathrm{SiO}_{2}$ increased (from $76.6 \%$ to $93.8 \%$ ), as well as, the component recovery of $\mathrm{MgO}$ increased (from $82.5 \%$ to $98.2 \%$ ) as the collector dosage increased from 0.6 to $1.2 \mathrm{~kg} / \mathrm{t}$. This may be interpreted due to that, at lower concentration of collector dosage, only the surface of faces (hydrophobic) can be float. When the collector increased, the surface of faces and edges (hydrophilic) become more hydrophobic [30]. In addition, at a collector concentration of $1.2 \mathrm{~kg} / \mathrm{t}$, the collector adsorbs on the negatively charged particle edges, thereby covering up the hydrophilic sites on the particle surface [2]. An excessive addition of collector dosages (above $1.2 \mathrm{~kg} / \mathrm{t}$ ) lead to an inverse effect and hence decreased the component recoveries of $\mathrm{SiO}_{2}$ and $\mathrm{MgO}$. Possibly, due to the development of collector multilayers on the particles, reducing the proportion of hydrocarbon radicals oriented into the bulk solution. The hydrophobicity of the particles is reduced and tends to float other minerals, reducing selectivity and floatability [29].

On the other hand, the component recoveries of $\mathrm{CaO}, \mathrm{Al}_{2} \mathrm{O}_{3}$ and $\mathrm{Fe}_{2} \mathrm{O}_{3}$ increased with increasing the collector dosages.

From Table 5a, it can be seen that the assays of $\mathrm{SiO}_{2}$ and $\mathrm{MgO}$ were at their lowest values in tailings, as well as, the assays of $\mathrm{CaO}, \mathrm{Al}_{2} \mathrm{O}_{3}$ and $\mathrm{Fe}_{2} \mathrm{O}_{3}$ were at their highest ones at the same value of collector dosage $(1.2 \mathrm{~kg} / \mathrm{t})$. This assures that the optimum conditions of these experiments are obtained at a collector dosage of $1.2 \mathrm{~kg} / \mathrm{t}$.

\section{Effect of Pulp Density}

Table 6a contains the chemical analysis of constituents in flotation products of experiments executed at different pulp densities. The table showed that the percentages of $\mathrm{SiO}_{2}$ and $\mathrm{MgO}$ (the major constituents of talc) decreased in the concentrate product with increasing the pulp density from 100 to $300 \mathrm{~g} / \mathrm{L}$. Conversely, the percentages of $\mathrm{CaO}, \mathrm{Al}_{2} \mathrm{O}_{3}$ and $\mathrm{Fe}_{2} \mathrm{O}_{3}$ (the main wastes in talc) increased. These results are illustrated also in Figures 4a through $\mathbf{4 e .}$

From Figures $\mathbf{4 a}$ and $\mathbf{4 b}$, it can be seen that, as the pulp density increased from 100 to $300 \mathrm{~g} / \mathrm{L}, \mathrm{SiO}_{2}$ decreased (from $57.60 \%$ to $54.23 \%$ ), as well as, $\mathrm{MgO}$ decreased (from $34.30 \%$ to $30.88 \%$ ).

Figures $4 \mathbf{c}$ through $4 \mathbf{e}$ revealed that $\mathrm{CaO}$ increased (from $0.29 \%$ to $0.68 \%$ ), $\mathrm{Al}_{2} \mathrm{O}_{3}$ increased (from $2.02 \%$ to $4.86 \%$ ), and $\mathrm{Fe}_{2} \mathrm{O}_{3}$ increased (from $5.59 \%$ to $8.04 \%$ ) as the pulp density increased from 100 to $300 \mathrm{~g} / \mathrm{L}$.

The effect of pulp density on the mass recovery of concentrate is shown in Table $6 \mathbf{b}$ and Fig. 4f. From this figure, it can be seen that, the mass recovery increased from $70.0 \%$ to $92.4 \%$, as the value of pulp density increased from 100 to $200 \mathrm{~g} / \mathrm{L}$. More increase of the pulp density, above $200 \mathrm{~g} / \mathrm{L}$, decreased the mass recovery.

The effect of pulp density on the component recoveries of constituents in concentrate is illustrated also in Table $\mathbf{6 b}$ and Fig. 4f. From this figure, it can be seen 
that the component recovery of $\mathrm{SiO}_{2}$ increased from $74.5 \%$ to $93.8 \%$, as well as, the component recovery of $\mathrm{MgO}$ increased from $80.3 \%$ to $98.2 \%$ as the pulp density increased from 100 to $200 \mathrm{~g} / \mathrm{L}$. Any increase of pulp density above $200 \mathrm{~g} / \mathrm{L}$ decreased the component recoveries of these constituents. Feng and Aldrich [23] stated that an $8 \%$ solids concentration was optimal with respect to the lowest recovery of talc. Higher pulp concentrations had a detrimental effect on flotation. Wills [29] has reported that the denser the pulp, the less cell volume is required in the commercial plant and fewer reagents are required, since the effectiveness of most reagents is a function of their concentration in solution. The optimum pulp density is of great important, as in general the more dilute the pulp, the cleaner the separation.

From Figure 4f, it can be seen that the component recoveries of $\mathrm{CaO}, \mathrm{Al}_{2} \mathrm{O}_{3}$ and $\mathrm{Fe}_{2} \mathrm{O}_{3}$ increased with increasing pulp densities.

From Table 6a, it can be seen that the assays of $\mathrm{SiO}_{2}$ and $\mathrm{MgO}$ were at their lowest values in tailings, as well as, the assays of $\mathrm{CaO}, \mathrm{Al}_{2} \mathrm{O}_{3}$ and $\mathrm{Fe}_{2} \mathrm{O}_{3}$ were at their highest ones at the same value of pulp density $(200 \mathrm{~g} / \mathrm{L})$. The whiteness improved from $75.4 \%$ to $83.7 \%$ and the loss on ignition decreased from $6.64 \%$ to $5.21 \%$ in the final product. This assures that the optimum condition of these experiments is obtained at a pulp density of $200 \mathrm{~g} / \mathrm{L}$.

Table 6a: The chemical analysis of flotation products of different experiments carried out at different pulp densities.

\begin{tabular}{|c|c|c|c|c|c|c|c|c|c|c|c|}
\hline \multirow{3}{*}{$\begin{array}{c}\text { Exp. } \\
\text { No. }\end{array}$} & \multirow{3}{*}{$\begin{array}{c}\text { Pulp } \\
\text { density, } \\
\text { g/L }\end{array}$} & \multicolumn{5}{|c|}{ Concentrate } & \multicolumn{5}{|c|}{ Tailings } \\
\hline & & \multicolumn{5}{|c|}{$\operatorname{Assay}\left(\mathbf{A}_{\mathrm{c}}\right), \%$} & \multicolumn{5}{|c|}{$\operatorname{Assay}\left(\mathrm{A}_{\mathrm{t}}\right), \%$} \\
\hline & & $\mathrm{SiO}_{2}$ & $\mathrm{MgO}$ & $\mathrm{CaO}$ & $\mathrm{Al}_{2} \mathrm{O}_{3}$ & $\mathrm{Fe}_{2} \mathrm{O}_{3}$ & $\mathrm{SiO}_{2}$ & $\mathrm{MgO}$ & $\mathrm{CaO}$ & $\mathrm{Al}_{2} \mathrm{O}_{3}$ & $\mathrm{Fe}_{2} \mathrm{O}_{3}$ \\
\hline 1 & 100 & 57.60 & 34.30 & 0.29 & 2.02 & 5.59 & 45.93 & 19.63 & 1.99 & 13.62 & 14.29 \\
\hline 2 & 150 & 56.24 & 33.07 & 0.34 & 2.63 & 6.49 & 43.43 & 14.09 & 3.09 & 19.82 & 16.73 \\
\hline 3 & 200 & 54.94 & 31.76 & 0.42 & 3.11 & 7.24 & 41.35 & 7.29 & 5.42 & 24.20 & 19.87 \\
\hline 4 & 250 & 54.75 & 31.65 & 0.52 & 3.69 & 7.83 & 50.56 & 20.36 & 2.33 & 15.37 & 10.22 \\
\hline 5 & 300 & 54.23 & 30.88 & 0.68 & 4.86 & 8.04 & 53.62 & 26.26 & 1.25 & 7.88 & 8.79 \\
\hline
\end{tabular}

Table $6 \mathrm{~b}$ : The mass recoveries of flotation products and the component recoveries of constituents of experiments executed at different pulp densities.

\begin{tabular}{|c|c|c|c|c|c|c|c|c|c|c|c|c|}
\hline \multirow{3}{*}{$\begin{array}{c}\text { Pulp } \\
\text { density, } \\
\text { g/L }\end{array}$} & \multicolumn{6}{|c|}{ Concentrate } & \multicolumn{6}{|c|}{ Tailings } \\
\hline & \multicolumn{5}{|c|}{ Component recovery $\mathbf{R}_{\mathrm{c}}(\mathbf{c}), \%$} & \multirow{2}{*}{$\begin{array}{c}\mathbf{R}_{\mathrm{m}}(\mathbf{c}), \\
\%\end{array}$} & \multicolumn{5}{|c|}{ Component recovery $R_{c}(t), \%$} & \multirow{2}{*}{$\begin{array}{c}\mathbf{R}_{\mathrm{m}}(\mathbf{t}), \\
\%\end{array}$} \\
\hline & $\mathrm{SiO}_{2}$ & $\mathrm{MgO}$ & $\mathrm{CaO}$ & $\mathrm{Al}_{2} \mathrm{O}_{3}$ & $\mathrm{Fe}_{2} \mathrm{O}_{3}$ & & $\mathrm{SiO}_{2}$ & $\mathrm{MgO}$ & $\mathrm{CaO}$ & $\mathrm{Al}_{2} \mathrm{O}_{3}$ & $\mathrm{Fe}_{2} \mathrm{O}_{3}$ & \\
\hline 100 & 74.5 & 80.3 & 25.4 & 25.7 & 47.7 & 70.0 & 25.5 & 19.1 & 74.6 & 74.3 & 52.3 & 30.0 \\
\hline 15 & 5.6 & 1 & 35.4 & 30 & 65.9 & 83.3 & 13.4 & 7.8 & 64.6 & 2 & 34.1 & 16.7 \\
\hline 0 & 3.8 & 2 & 48.5 & 5 & 81 & 9 & 6.2 & 1 & 51.5 & 7 & 18.4 & 7.6 \\
\hline 250 & 85.5 & 89.5 & 54.9 & 56.7 & 80.7 & 5 & 14.5 & 5 & 45.1 & 43.3 & 19.3 & 15.5 \\
\hline 300 & 78.0 & 81.4 & 67.0 & 69.6 & 77.3 & 78.8 & 22.0 & 18.6 & 33.0 & 30.4 & 22.7 & 21.2 \\
\hline
\end{tabular}




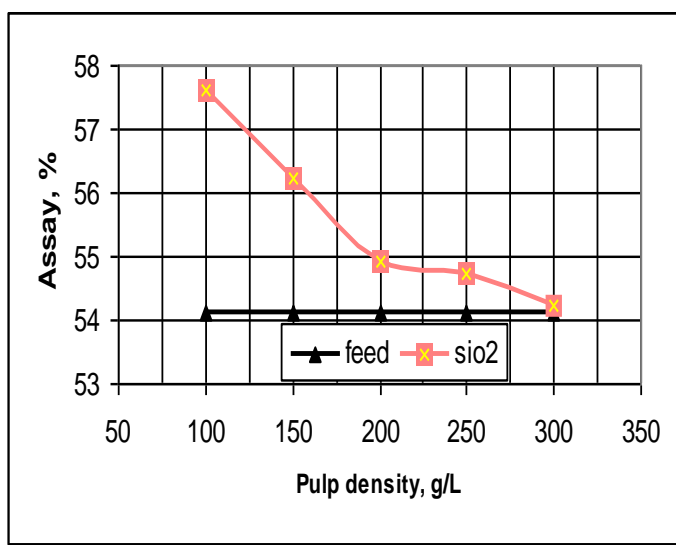

Fig. 4a: $\mathrm{SiO}_{2}$ assay with pulp density.

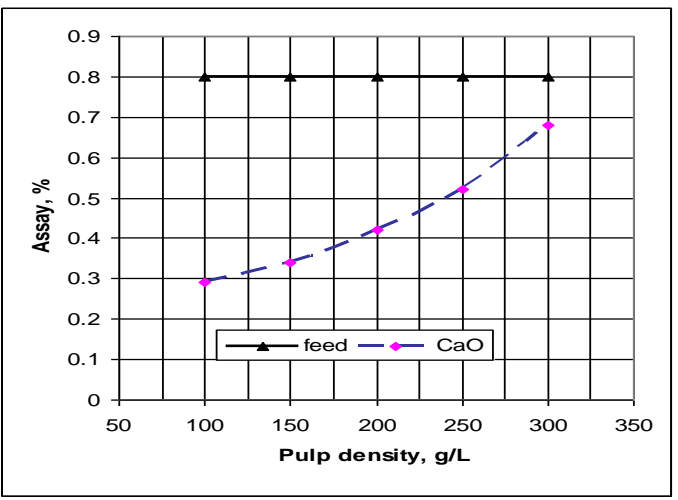

Fig. 4c: $\mathrm{CaO}$ assay with pulp density.

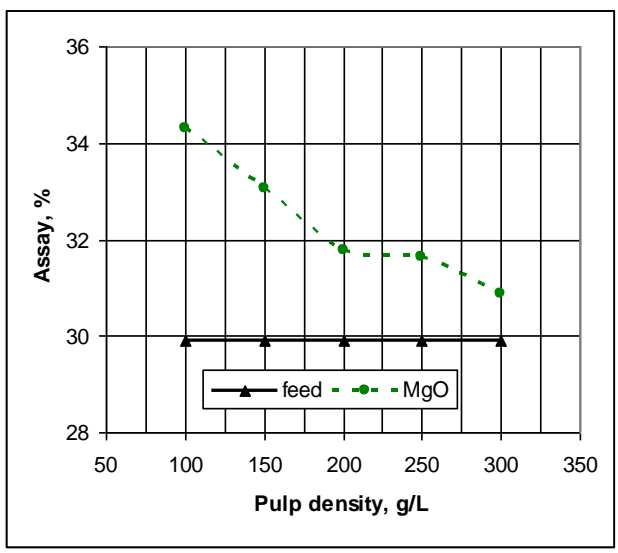

Fig. 4b: MgO assay with pulp density.

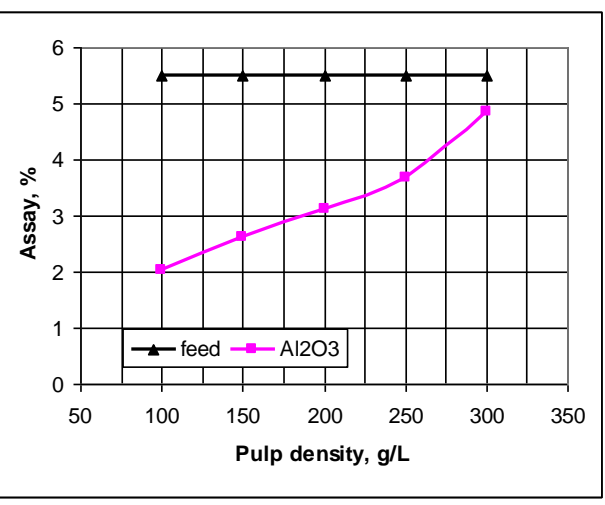

Fig. 4d: $\mathrm{Al}_{2} \mathrm{O}_{3}$ assay with pulp density.

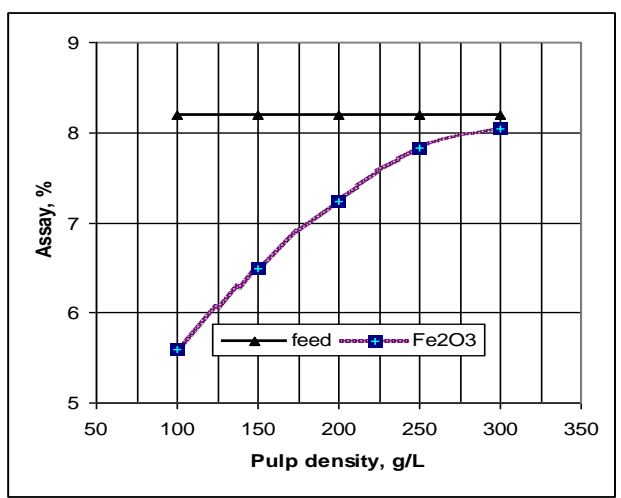

Fig. 4e: $\mathrm{Fe}_{2} \mathrm{O}_{3}$ assay with pulp density.

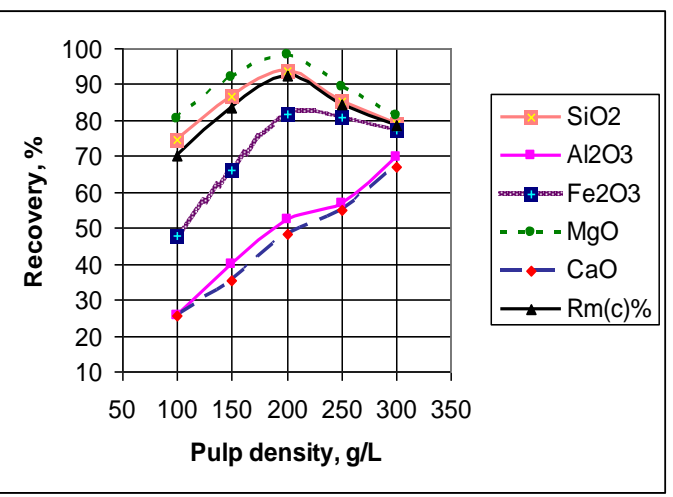

Fig. 4f: Mass and component recoveries with pulp density.

Fig. 4: Effect of pulp density on the mass recovery, as well as, on the assays and component recoveries of different constituents in concentrate. 
From Table 6 and Fig. 4, it can be seen that there are another operating conditions, which give better result of the characteristics of talc in concentrate but with lower mass recovery. This conclusion was obtained at a pulp density of $100 \mathrm{~g} / \mathrm{L}$. At this condition, the assays of $\mathrm{SiO}_{2}(57.60 \%)$ and $\mathrm{MgO}(34.30 \%)$ were at their highest values in concentrate, as well as, the assays of $\mathrm{CaO}(0.29 \%), \mathrm{Al}_{2} \mathrm{O}_{3}(2.02 \%)$ and $\mathrm{Fe}_{2} \mathrm{O}_{3}$ $(5.59 \%)$ were at their lowest ones. The mass recovery was the lowest one $(70 \%)$, as well as, the component recovery of talc constituents were also the lowest ones $(74.5 \%$ and $80.3 \%$ respectively).

\section{Leaching of Final Concentrate of Flotation}

More improvement of talc quality was obtained by leaching of final concentrate of flotation with a dilute hydrochloric acid having a concentration of $10 \%$, solid-liquid ratio (1:2), at a temperature of $60^{\circ} \mathrm{C}$ for a period of 30 minutes using a mechanical stirrer. The residues of leaching process were washed with acidulated hot water and then with pure water. After the process being finished, the concentrate was dried, weighed and chemically analyzed. The final results of chemical analysis of talc constituents, mass recovery, whiteness, and loss on ignition in feed, final concentrate of flotation, and leaching product are shown in Table 7. The mass recovery of final product was about $85 \%$ of initial feed. In this final product, $\mathrm{Fe}_{2} \mathrm{O}_{3}$ decreased to $3.12 \%$, $\mathrm{CaO}$ decreased to $0.38 \%$, and $\mathrm{Al}_{2} \mathrm{O}_{3}$ decreased to $3.01 \%$. The assay of $\mathrm{SiO}_{2}$ increased to $58.96 \%, \mathrm{MgO}$ percent was nearly the same, the whiteness increased to $88.5 \%$, and the loss on ignition decreased to $4.03 \%$. The improvement of whiteness may be attributed to the reduction of iron content in the final product.

Table 7: The final results of chemical analysis of talc constituents, mass recovery, whiteness, and loss on ignition in feed, final concentrate of flotation, and leaching product.

\begin{tabular}{|c|c|c|c|c|}
\hline \multicolumn{2}{|c|}{} & Feed & $\begin{array}{c}\text { Final concentrate of } \\
\text { flotation }\end{array}$ & $\begin{array}{c}\text { Leaching } \\
\text { Product }\end{array}$ \\
\hline \multirow{4}{*}{ Assay, \% } & $\mathbf{S i O}_{2}$ & 54.10 & 54.94 & 58.96 \\
& $\mathbf{M g O}$ & 29.90 & 31.76 & 31.73 \\
& $\mathbf{C a O}$ & 0.80 & 0.42 & 0.38 \\
& $\mathbf{A l}_{2} \mathbf{O}_{3}$ & 5.50 & 3.11 & 3.01 \\
& $\mathbf{F e}_{2} \mathbf{O}_{3}$ & 8.20 & 7.24 & 3.12 \\
\hline \multicolumn{2}{|c|}{ Mass recovery, \% } & 100 & 92.40 & 85.00 \\
\hline \multicolumn{2}{|c|}{ Whiteness, \% } & 75.4 & 83.7 & 88.5 \\
\hline \multicolumn{2}{|c|}{ Loss on ignition, \% } & 6.64 & 5.21 & 4.03 \\
\hline
\end{tabular}

\section{CONCLUSIONS}

From the results of this investigation, the following conclusions can be drawn:

1. The floatability of talc increased as the $\mathrm{pH}$ increased up to a value of 11. Above this value, the floatability of talc decreased.

2. The $\mathrm{CaO}$ and $\mathrm{Al}_{2} \mathrm{O}_{3}$ can be partially sequestered using sodium hexametaphosphate as a selective depressant at a certain limit. The optimum value was found at 1.0 $\mathrm{kg} / \mathrm{t}$. 
3. The floatability of talc depends upon its degree of hydrophobicity. This hydrophobicity increased with increasing the collector dosage up to $1.2 \mathrm{~kg} / \mathrm{t}$.

4. The recovery of talc increased as the pulp density increased up to $200 \mathrm{~g} / \mathrm{L}$, above which the recovery of talc decreased.

5. At the optimum operating variables of flotation process, $\mathrm{SiO}_{2}$ assay increased (from $54.10 \%$ to $54.94 \%$ ), $\mathrm{MgO}$ assay increased (from $29.90 \%$ to $31.76 \%$ ), $\mathrm{CaO}$ decreased (from $0.80 \%$ to $0.42 \%$ ), $\mathrm{Al}_{2} \mathrm{O}_{3}$ decreased (from $5.50 \%$ to $3.11 \%$ ), $\mathrm{Fe}_{2} \mathrm{O}_{3}$ decreased (from $8.20 \%$ to $7.24 \%$ ), the whiteness increased from $75.4 \%$ to $83.7 \%$, and the loss on ignition decreased from $6.64 \%$ to $5.21 \%$. The mass recovery of final concentrate was $92.4 \%$. The component recoveries of $\mathrm{SiO}_{2}$ and $\mathrm{MgO}$ (the major constituents of talc) in the final concentrate were $93.8 \%$ and $98.2 \%$, respectively.

6. The final concentrate of flotation was leached with a dilute hydrochloric acid $(10 \%)$. In the final product, $\mathrm{SiO}_{2}$ assay increased to $58.96 \%, \mathrm{MgO}$ assay was nearly the same, $\mathrm{CaO}$ decreased to $0.38 \%, \mathrm{Al}_{2} \mathrm{O}_{3}$ decreased to $3.01 \%$, and $\mathrm{Fe}_{2} \mathrm{O}_{3}$ decreased to $3.12 \%$. The mass recovery was about $85 \%$ of the initial feed, whiteness was improved to $88.5 \%$, and the loss on ignition decreased to $4.03 \%$.

7. The final product is suitable for many industrial uses such as low-loss electronics (a type of ceramics), paints, rubber, plastics, roofing, textiles, refractories, insecticides and coating of welding rods.

\section{REFERENCES}

[1] Boghdady, G.Y., Ahmed, M.M., Ibrahim, G.A. and Hassan, M.M.A., "Petrographical and geochemical characteristion of some Egyptian talc samples for possible industrial applications", Journal of Engineering Science, Assiut University, Vol. 33, No. 3, pp. 1001-1011, 2005.

[2] Fuerstenau, D.W. and Huang, P., "Interfacial phenomena involved in talc flotation and depression", ХХП International Mineral Processing Congress, South Africa, pp. 1034-1043, 2003.

[3] Ozkan, A., "Coagulation and flocculation characteristics of talc by using different flocculants in presence of cations", Minerals Engineering, Vol. 16, pp. 59-61, 2003.

[4] Yehia, A. and AL-Wakeeel, M.I., "talc separation from talc-carbonate ore to be suitable for different industrial applications", Minerals Engineering, Vol. 13, No. 1, pp. 111-116, 2000.

[5] Khraisheh, M., Holland, C., Creany, C., Harries, P. and Parolis, L., "Effect of molecular weight and concentration of the adsorption of CMC onto talc at different ionic strengths", International Journal of Mineral Processing, Vol. 75, pp. 197-206, 2005.

[6] Morris, G.E., Fornasiero, D. and Ralston, J., "Polymer depressants at the talcwater interface: adsorption isotherm, microflotation and electrokinetic's studies", International journal of Mineral Processing, Vol. 67, pp. 211-227, 2005.

[7] Sarquis, P.E. and Gonzalez, M., "Limits of the use of industrial talc-the carbonate effect", Minerals Engineering, Vol. 11, No. 7, pp. 657-660, 1998. 
[8] Simandle, G.J. and Paradis, S.P., "Carbonate-hosted talc", Industrial Minerals, British Columbia Mineral Deposits Profiles Doc. Ministry of Energy and Mines(Canada), Vol. 3, pp. 1-6, 1999.

[9] Al-Wakeeel, M.I., "Geology and beneficiation of some Egyptian talc- carbonate rocks", Ph.D. Thesis, Ain Shams University, Egypt, pp. 313-365, 1996.

[10] Schober, W., "Quality compounds require premium talc grades and sophisticated formulations", Eurofillers97-filler. Doc, Manchester (UK), PP. 1-12, September $8^{\text {th }}-11^{\text {th }}, 1997$.

[11] Andrews, P.R.A., "Laboratory study of the flotation circuit at Baker talc Inc., high water, Quebec", CIM Bulletin, Vol. 78, No. 884, pp. 75-78, 1985.

[12] Helmy, A.K., Ferreiro, E.A. and de Bussetti, S.G., "The surface energy of talc", Journal of Colloid and Interface Science, Vol. 285, pp. 314-317, 2005.

[13] Chandra, N., Agnihotri, N. and Kumar, S., "Sintering characteristic of talc in the presence of phosphates and alkali carbonate sintering activators", Ceramics International, Vol. 30, pp. 643-652, 2004.

[14] Okunlola, O.A., Ogedengbe, O. and Ojutalyo, A., "Composition features and industrial appralsal of the Babe Ode talc occurrence, south western Nigeria", Global Journal of Geological Science, Vol. 1, No. 1, pp. 63-72, 2003.

[15] Feerage, E., Martin, F., Micoup, P., Petit, S., de Parseval, P., Beziat, D. and Ferret, J., "Cation site distribution in clinochlores a NIR approach", Clay Minerals, Vol. 38, pp. 329-338, 2003.

[16] Feerage, E., Martin, Petit, S., Soucaille, S., Micoup, P., Fourty, G., Ferret, J., Salvi, S., de Parseval, P. and Fortune, J.P., "Evaluation of talc morphology using FTIR and H/D substitution", Clay Minerals, Vol. 38, pp. 141-150, 2003.

[17] Chang, L.L.Y., "Industrial mineralogy", Prentice Hall, Inc. Publication, pp. 398407, 2002.

[18] Houot, R., Joussemet, R., Yang, S. and Baeza, R., "Beneficiation of talceouse products", Processing of Hydrophobic Minerals and fine Coal, Proceeding of The $34^{\text {th }}$ Annual Conference of Metallurgies, CIM, pp. 373-377, 1995.

[19] Boulos, T.R., "Transforming upgrading of talc for different industrial application", Final Report supmeted to the Egyptian Academy for Scientific Research and Technology, pp. 1-54, 2004.

[20] Piga, L. and Marruzz, G., "Preconcentration of an Italian talc by magnetic separation and attrition", International Journal of Mineral Processing, Vol. 35, pp. 291-297, 1992.

[21] Andrews, P.R.A., "Pilot-plant treatment of Quebec talc ore", CIM Bulletin, Vol. 82, No. 932, pp. 76-81, 1989.

[22] Kho, C.J. and Sohn, H.J., "Column flotation of talc", International Journal of Mineral Processing, Vol. 27, pp. 157-167, 1989.

[23] Feng, D. and Aldrich, C., "Effect of ultrasonication on the flotation of talc", Ind. Eng. Chem., Vol. 43, pp. 4422-4427, 2004.

[24] Rath, R.K., Subramnian, S. and Laskowski, J.S., "Adsorption of guar gum onto talc", Processing of Hydrophobic Minerals and fine Coal, Proceeding of The $34^{\text {th }}$ Annual Conference of Metallurgies, CIM, pp. 105-119, 1995.

[25] Bremmell, K.E. and Mensah, J., "Interfacial-chemistry mediated behavior of colloidal talc dispersions", Journal of Colloid and Interface Science, Vol. 283, Issue 2, pp. 385-391, 2005. 
[26] Zhenghe, X., Plitt, V. and Liu, Q., "Recent advances in reverse flotation of diasporic ores", Minerals Engineering, Vol. 17, pp. 1007-1015, 2004.

[27] Andreola, F., Castellili, E., Manfredini, T. and Romagnoli, M., "The role of sodium hexametaphosphate in the dissolution process of kaolinite and kaolin", Journal of the European Ceramic Society, Vol. 24, pp. 2113-2124, 2004.

[28] Andreola, F., Castellili, Ferreira, J.M.F., Olhero, S. and Romagnoli, M., "Effect of sodium hexametaphosphate and ageing on the rheological behavior of kaolin dispersions", Applied Clay Science, Vol. 31, pp. 56-64, 2006.

[29] Wills, B.A., "Mineral processing technology", Pergamon Press., $5^{\text {th }}$ ed., pp. 497500, 1992.

[30] Ahmed, M.M., "Kinetics of Maghara coal flotation", M.Sc. Thesis, Assiut University, Egypt, pp. 73-78, 1995.

\section{تحسين جودة خام التلك المصرى للأغراض الصناعية باستخدام التعويم بالهواء والإذابة بالأحماض الصناع}

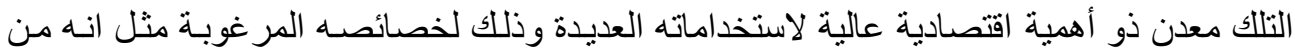

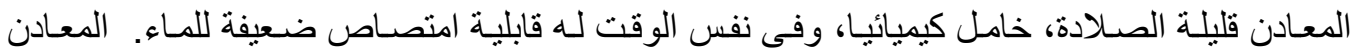

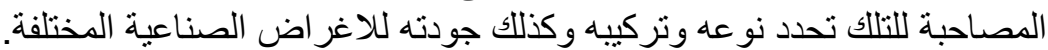

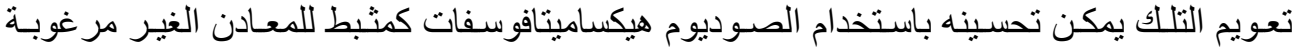

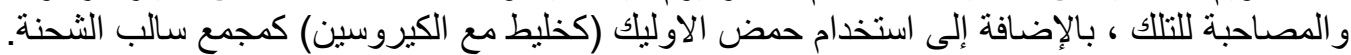

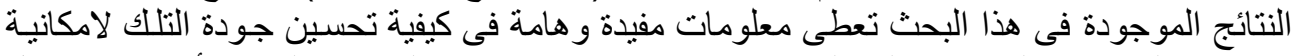

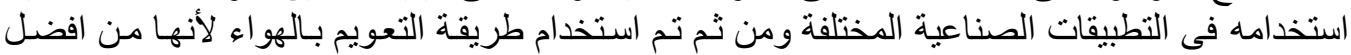
الطرق بالنسبة لهذه النوعية من الخامات.

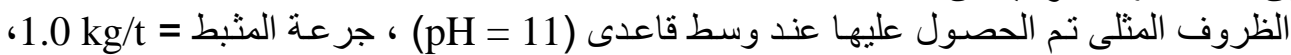

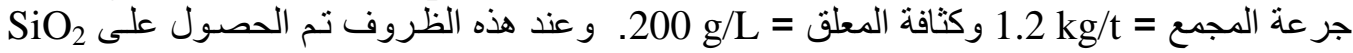

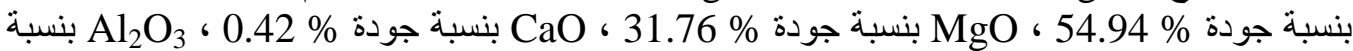

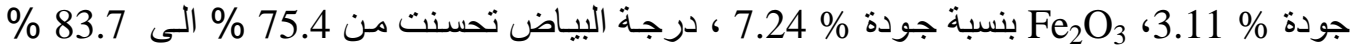

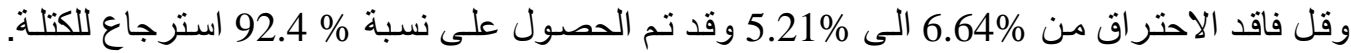
و عند هذه الظروف المثلى كان استرجاع المكونـات الرئيسية للتلك كلآتى:

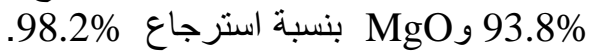

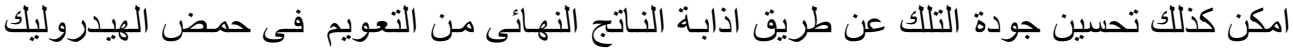
المخفف عند تركيز 10\%. وباستخدام هذه الطريقة تم الحصول على

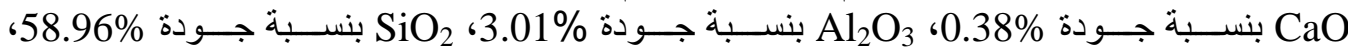

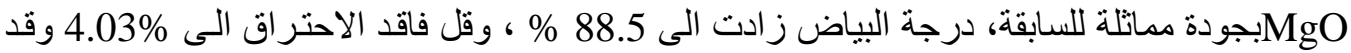

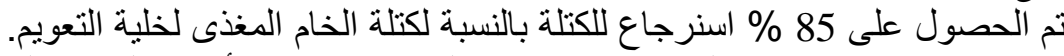

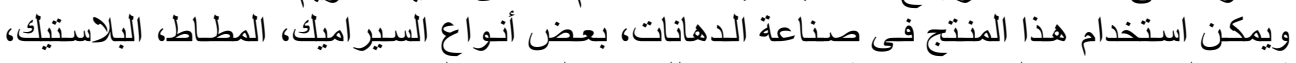
التغطيات، المنسوجات، الحراريات، طلاء قضبان اللحام، و المبيدات الحشرية. 